\title{
WYPARTE HISTORIE XIX WIEKU
}

\author{
KATARZYNA CZECZOT, WIKTOR MARZEC, MiCHAŁ POSPISZYL
}

W prezentowanym numerze Praktyki Teoretycznej stawiamy sobie stosunkowo skromne zadanie. Naszym celem nie było opowiedzenie (całej) wypartej historii dziewiętnastego wieku, ani nawet stworzenie mapy umożliwiającej wyznaczenie potencjalnie interesujących pod tym względem obszarów. Ich wielość i programowa niejednolitość możliwych perspektyw badawczych sprawiaja, że zadanie takie nie byłoby możliwe do wykonania, a być może nawet winno zostać świadomie porzucone. Zależało nam natomiast na czterech sprawach. Po pierwsze, na wypracowaniu metody dającej szanse na odkrycie świata historycznego, który zostaje w dominującej dziś historiografii albo zignorowany, albo opowiedziany w sposób zdawkowy i powierzchowny. Po drugie, na przedstawieniu tej metody w działaniu, w analizach konkretnych opowieści, dokumentów, w badaniach wypartych i zneutralizowanych wydarzeń. Po trzecie, na rejestracji rzeczywistych historycznych antagonizmów, niewidocznych po tym, jak ukonstytuowała się dominująca i gładka wizja historii dziewiętnastego wieku, z której wyparto historię walk klasowych i towarzyszących im radykalnych projektów społecznych. W końcu, po czwarte, na wypracowaniu innego pojęcia nowoczesności, w którym emancypacja i postęp nie będą dłużej ujmowane w sposób linearny, ale które pozwoli uwzględnić historycznie zmienne pola sił. Większość z zamieszczonych w numerze artykułów (w każdym wypadku inaczej rozkładając akcenty) próbuje sprostać tym czterem zadaniom. 
W tym kalejdoskopowym obrazie dziewiętnastego wieku czytelniczka może znaleźć perspektywę odpowiednią dla własnego sposobu widzenia i pisania historii zajmującego nas okresu. Nielinearność ukrytej historii nie może jednak prowadzić do metodologicznej dezynwoltury i arbitralnej pracy ze źródłami. Chodzi raczej o powrót do tekstu niż o jego reinterpretację wedle odgórnie ustalonych kryteriów. Taka lektura ujawnia antagonizmy, nie pozwalając nam zawierzyć jednogłosowej (i jednogłośnej) prezentacji interesującej nas epoki.

W poszukiwaniu narzędzi przydatnych do innego badania historii dziewiętnastego wieku za punkt wyjścia bierzemy uwagi metodologiczne z późnych pism Waltera Benjamina. To właśnie temu zagadnieniu poświęcony jest esej Arlette Farge. Francuska historyczka przekonuje, że „niewzruszona i linearna, pozbawiona pęknięć i chropowatości podstawa pozycji historyka pod wpływem lektury Benjamina rozpada się”. Wzięcie Benjaminowskich uwag na serio prowadzić musiało bowiem do efektów ,analogicznych do techniki rozszczepienia atomu - wyzwalając ogromne energie historii uwięzione w «było sobie pewnego razu» tradycyjnej historiografii”. Odkrycie zapomnianych, stłumionych emocji, marzeń czy projektów wymaga w pierwszej kolejności rozregulowania czy wręcz porzucenia utartych sposobów widzenia. To podstawowy warunek umożliwiający dotarcie do niewidzianej warstwy historii. Zdaniem Farge dokładnie tak postępowała cała dwudziestowieczna krytyczna historiografia (zwłaszcza ta spod znaku Michela Foucaulta oraz Michela de Certeau). W przedsięwzięciu tym nie chodzi jednak tylko o odkrycie utraconych światów podległej podmiotowości, owych stłumionych marzeń, emocji i projektów. Jest to także propozycja odnowienia materializmu historycznego.

W centrum tak pojmowanego materializmu historycznego nie stoi przeszłość rozumiana jako jednorodny przepływ kolejnych epok czy formacji. Celem jest dotarcie do uwikłanych w antagonizmy osobistych i klasowych światów, podważających sztywne struktury tradycyjnej historiografii ujednolicającej przeszłość zgodnie z percepcją „zwycięzców”. Poważnym problemem, przed którym staje tak ujmowany historyczny materializm, są źródła. Jak badać świat niepiśmiennej większości? Jak dotrzeć do rzeczywistości, która ujawnia się wyłącznie we fragmentach, skrawkach albo też w zapośredniczonych narracjach sporządzanych przez kogoś innego? Zgodnie z kolejną wskazówką Benjmiana historia powszechna to tak naprawdę historia klas podporządkowanych. Dotyczy ona „większości”, jednak rzadko rozgrywała się w centrum oficjalnego życia społecznego. Jej domena jest zatem margines, krawędź, próg, a więc miejsce pomiędzy tym, co całkowicie zewnętrzne, a tym, co wewnętrzne. To dlatego Benjaminowski historyk nie jest nihilista poznawczym, dla którego brak bezpośrednich źródeł o życiu klas podporządkowanych wyklucza możliwość prowadzenia badań. Nie jest jednak także pozytywista, biorącym za dobra monetę dokumenty, obrazy i teksty wytwarzane przez klasy panujące. Historyk ów proponuje uważne, krytyczne śledzenie dostępnego materiału, szukanie w dominujących narracjach sprzeczności, napięć czy konfliktów. 
Niezwykłe z tej perspektywy jest zadanie, które postawiła sobie Carolyn Steedman. Korzysta ona z dziennika anglikańskiego pastora żyjącego w latach 1719-1806 w niewielkiej osadzie w hrabstwie Yorkshire, Johna Murgatroyda, by odtworzyć historię jego służącej, Phoebe Beatson. Ambicją badaczki jest tu włączenie do historii społecznej nieobecnej w niej dotąd klasy - służby domowej; ale nie tylko to. Jest nią również zakwestionowanie założeń klasycznej historiografii poprzez umieszczenie w centrum opowieści postaci, które nijak nie pasują do utrwalonych wyobrażeń na temat osiemnastego i dziewiętnastego wieku. Gdy Phoebe Beatson zachodzi w ciążę z parobkiem z sąsiedztwa, a ten nie daje się nakłonić do ożenku, jej pracodawca nie tylko nie oddala jej ze służby, ale i pozwala na to, by dziecko urodziło się iwychowywało w jego domu. Steedman podkreśla, że dzieje tej relacji nie są niezwykłe jako takie. Są natomiast niezwykłe na tle obowiązującej wykładni historii społecznej, która usiłując wyznaczyć związek między ogólną sytuacją polityczno-ekonomiczną a zachowaniem ludzi, służy w gruncie rzeczy do zakrywania biografii ludzi takich jak Phoebe Beatson czy John Murgatroyd. Dlatego Steedman proponuje, by założyć na chwilę, że taki związek nie istnieje, i by „spróbować pomyśleć, że to zachowania i ludzkie relacje same mają moc kształtowania życia". To rozwiązanie - w przypadku historii proletariatu, uwikłanej w deterministyczne kategorie - nabiera szczególnego znaczenia. Steedman kreśli projekt historii, która będzie w stanie „dostrzec Ciebie, już nie jako ciche potwierdzenie demograficznej tendencji [...] i już nie jako bierne odzwierciedlenie przesunięć realnych płac dla robotnic przemysłu tekstylnego, ale jako aktorkę swojego własnego życia”.

Z podobnej pozycji historię przedrewolucyjnej Francji próbuje opowiedzieć w swoim artykule Gabriel Klimont. Zamiast ograniczać się do nowej interpretacji znanych wszystkim wydarzeń, Klimont wychodzi od krytycznej lektury kanonicznego dla historiografii rewolucji dzieła Alexisa de Tocqueville'a. Celem nie jest jednak pozytywistyczna weryfikacja (z oczywistych względów pełnej błędów) narracji dziewiętnastowiecznego filozofa, ale przyjrzenie się maszynom konserwatywnej historiografii w działaniu. Klimont proponuje czytać Tocqueville’a jako autora przerażonego rewolucja, skonfrontowanego z historyczną traumą i próbującego ową traumę oswoić. Tocqueville czyni to, opowiadając dzieje wielkiej rewolucji tak, by ta mogła jawić się jako wytwór - oderwanych od rzeczywistości oświeceniowych elit. Zadanie, jakie stawia sobie Klimont, polega na odzyskaniu z francuskich wydarzeń tego, co tak bardzo przeraziło Tocqueville’a. Dlatego zestawia jego tekst z pamfletami wspóltworzonymi przez francuską biedotę, których lektura pozwala ocenić, jak istotna była historyczna sprawczość owej biedoty. Ta ostatnia zaś nie tylko wpływała na bieg wydarzeń, ale tworzyła własne pisma czy pamflety przedstawiające pozytywną wizję społecznej zmiany, dużo bardziej radykalnej niż ta, którą można wyczytać z pism oświeceniowych filozofów. 
Inaczej niż Klimont i Steedman, Piotr Laskowski pracuje przede wszystkim na źródłach wytworzonych przez same klasy podporządkowane. W tekście poświęconym żydowskiej robotnicy domowej Etli Bomsztyk analizuje wspomnienia bohaterki artykułu. Mimo że biografia proletariuszki nie jest zapośredniczona przez historiografię klas dominujących, to także w tym wypadku badane dokumenty czytane sa pod włos. Bomsztyk zostawiła po sobie trzy relacje: jedną spisana w 1953, druga nagraną w 1966 i w końcu trzecią - nigdy nieopublikowana, a zarazem najbardziej osobista - z roku 1953. Zamiast układać z dostępnego materiału spójną biografię, Laskowski próbuje przede wszystkimi wykryć obecne w tych trzech relacjach napięcia. W efekcie obok przewidywalnego głosu działaczki partyjnej i związkowej (później sprawnie poruszającej się w ramach liberalnej sfery publicznej) mamy szanse usłyszeć głos rzeczywistej robotnicy, naznaczony jej emocjami, marzeniami, lękami. To właśnie odkrywanie takich materialnych opowieści: pełnych nędzy i cierpienia, ale także ogromnych nadziei, ma rozstrajać nawyki impregnowanego na rzeczywistość historyka.

Nie tylko świat osobistych przeżyć znika z pola widzenia w perspektywie tradycyjnej historiografii. Dlatego kolejny blok tekstów poświęcony jest praktykom kreującym społeczna autonomię kultury proletariackiej. Z badań Françoisa Fourna, poświęconych socjalistycznym i komunistycznym broszurom pisanym w latach czterdziestych dziewiętnastego wieku, wyłania się zupełnie nowy obraz francuskiego proletariatu. Fourn analizuje nie tyle treści propagandowych materiałów, ile metody ich produkcji, kanały rozpowszechniania, praktyki czytelnicze. To przesunięcie akcentu z zawartości broszur na sposób ich funkcjonowania czy strategie odbioru służy uwydatnieniu roli, jaką w kształtowaniu się lewicowego języka pełnili czytelnicy tych publikacji. Fourn podkreśla, że robotnicy nie tylko sami pisali wiersze i pamflety, ale byli również krytycznymi odbiorcami socjalistycznej propagandy. Ich zróżnicowane reakcje znajdowały odbicie w kolejnych publikacjach. Wizja, którą tworzy Fourn, daleka jest od obrazu jednowektorowej transmisji wiedzy, wytwarzanej przez intelektualistów i biernie przyswajanej przez robotników. Ideologiczny przekaz był twórczo negocjowany w obrębie prywatnej i autonomicznej polityki.

Równie złożony obraz wyłania się z opisu kultury proletariackiej przedstawionego w słynnej pracy Jacques'a Rancière'a La nuit des prolétaires, której fragment publikujemy w tym numerze. Choć głównym przedmiotem analizy Rancière'a jest dziewiętnastowieczna produkcja kulturowa robotnic i robotników, to celem francuskiego filozofa nie jest obrona tezy o absolutnej (kartezjańskiej) autonomii kultury robotniczej. Materiał, z którego kształtuje się ta kultura, jest dostępny jako pozostałość po wcześniejszych kulturach ludowych i jako zastana forma kultury wysokiej. Takie polityczno-kulturowe majsterkowanie, jakie pokazuje Rancière, a także oddolnie powstające literatura, prasa, teatr itd., są odpowiedzią na potrzeby historycznej chwili, ale też wykraczaja poza określone cele. Autor polemizuje jednocześnie z co najmniej dwoma stereotypami - pierwszym, zgodnie z którym lud to tylko klasa „żywicieli”, niezdolna 
do działalności kulturotwórczej, i drugim - który ludowe święta i rytuały uznaje za akty „wspólnictwa w podporządkowaniu”, rozpraszające jedynie energię sprzeciwu. Rancière dostrzega, że polityczna emancypacja była często pochodną owych partykularnych spotkań, sporów, dyskusji i roszczeń, i więcej zawdzięcza ona prowizorycznym, ale oddolnym rozwiązaniom niż politycznym przewrotom zmieniającym tylko nazwę obowiązującej monarchii.

Sprzecznościom obecnym w literaturze i walkom toczonym w tym polu przyglądają się w swoich tekstach Paweł Tomczok i Kristin Ross. Zamiast z mniej lub bardziej fragmentarycznych źródeł rekonstruować świat klas podporządkowanych, analizują oni kulturę dominująca. W tej perspektywie wysoka literatura okazuje się tyleż symptomem materialnych walk klasowych, ideologicznym narzędziem mającym służyć legitymizacji przemocy i zastanych stosunków społecznych, ile autonomiczną przestrzenią walki politycznej. W efekcie analizowane przez Ross - dzieje późnodziewiętnastowiecznej literatury francuskiej przestaja być sceną sporów czysto estetycznych, a okazują się dotykać materialnych procesów społecznych: kolonializmu, Komuny Paryskiej, walki klas.

Na przecięciu zasygnalizowanych wyżej trzech obszarów uwidacznia się jeszcze jedna, kluczowa dla podjętej w numerze problematyki kwestia. Dotyczy ona języka. Wyzwaniem „metodologicznym” była praca z podwójnie zapośredniczonymi źródłami, przedstawiającymi jedynie symptomy doświadczenia obcego dla elitarnego języka, w którym je spisano. Zarazem język był nośnikiem emancypacji i przestrzenia autonomii, gdy robotnicy przechwytywali pojęciowe zasoby dostarczane im przez partyjne proklamacje i dostosowywali je do własnego sposobu pojmowania oraz przekształcania świata. W języku ujawniały się napięcia istniejące w usytuowanej historycznie i klasowo produkcji literackiej. We wszystkich tych obszarach podstawą rozumienia świata było jego nazwanie. Dziewiętnasty wiek to okres, w którym nadano imiona podstawowym grupom społecznym przemysłowego kapitalizmu. Te pojęcia, zasklepiające w sobie wielość doświadczeń i interesów, były zarówno narzędziem ujednolicenia historycznego doświadczenia za pomoca skostniałych kategorii (np. klasy robotniczej), jak i wehikułami walki (prowadzonej przez tę samą klasę robotnicza). Dlatego konkretny kształt pojęć i ich zmiana zachodząca w czasie to kwestie istotne dla pisania wypartej historii w sposób historyczny (a zatem nie ahistoryczny) - ze świadomością projekcyjnych właściwości pojęć, z pomocą których pisano źródła i z pomocą których my piszemy historię. Piotr Kuligowski bada sposoby konceptualizacji klasy robotniczej w kręgach polskiej lewicy pomiędzy 1832 a 1892 rokiem i dostarcza informacji na temat „robotników” w polskim dziewiętnastym wieku. Felipe Ziotti Narita używa natomiast języka jako wytrychu, który pozwala mu odsłonić świat moralnych wyobrażeń, składających się na inną nowoczesność targaną sprzecznymi impulsami. Czytając gazety i podręczniki, ujawnia warunki reprodukcji i „ujednolicenia” miejskiej nowoczesności w „peryferyjnym” kontekście brazylijskiej metropolii. 
Intensywność a także złożoność walk toczonych w długim dziewiętnastym wieku czyni tę epokę szczególnie interesująca. Stąd prezentowana przez nas w tym numerze perspektywa stanowi próbę wyjścia poza ujęcia tego okresu, które zdominowały nie tylko historiografie konserwatywne, ale także tradycyjnie marksistowskie (jak te obecne w pracach Edwarda Palmera Thompsona czy Erica Hobsbawma). Zamiast koncentrować się na abstrakcyjnych i jednorodnych tendencjach (mających w prosty sposób wyjaśniać całą złożoność epoki), próbujemy przemyśleć historiografię od strony innego pojęcia materii. Dlatego nowy materializm historyczny, zamiast podporządkowywać bierną materię życia społecznego idealistycznym dziejowym determinizmom, staje się tu metodą umożliwiającą odkrycie materii aktywnej, twórczej, zdolnej do zaskakujących przekształceń.

Z tego powodu głównym tematem numeru nie jest ani industrialny kapitalizm, ani klasa robotnicza rozumiana jako homogeniczny podmiot, są nim za to robotnice domowe, wiejski motłoch, drobni rzemieślnicy, radykalni poeci. Ich walki, choć w większości zakończyły się klęska, wpłynęły na bieg historii, wytwarzając przestrzeń autonomii umożliwiającej produkcję radykalnych projektów społecznych. To za sprawą tych walk (i ich kruchych sukcesów) wiemy, że komunizm nie jest abstrakcyjnym pojęciem, nieokreślonym zwieńczeniem pochodu dziejowego, ale stał się materialną praktyką rozwijaną na ulicach, strychach, fabrykach, suterenach i wszędzie tam, gdzie uciskane i uciskani w walce z przemocą organizowali sieci solidarności i wzajemnej pomocy.

CYTOWANIE: Czeczot, Katarzyna, Wiktor Marzec i Michał Pospiszyl. 2017. „Wyparte historie XIX wieku" Praktyka Teoretyczna 1(23): 8-13.

DOI: $10.14746 /$ prt.2017.1.0

AUTHORS: Katarzyna Czeczot, Wiktor Marzec, Michał Pospiszyl

TITLE: Repressed Histories of the 19th Century

ABSTRACT: A short introduction to the special issue of the Theoretical Practice Journal. 